\title{
Anatomical Characterization of the Adventitious Roots of Mate (Ilex paraguariensis A. St.-Hil.) Mini-cuttings
}

\author{
Nathalia Pimentel ${ }^{1}$ \\ https://orcid.org/0000-0002-2584-1223 \\ Marina Favarin Pedroso ${ }^{1}$ \\ https://orcid.org/0000-0001-9289-8919 \\ Kelen Haygert Lencina ${ }^{2}$ \\ https://orcid.org/0000-0001-5777-5569
}

João Marcelo Santos de Oliveira ${ }^{3}$

https://orcid.org/0000-0002-6022-1767

\section{Dilson Antônio Bisognin ${ }^{1^{\star}}$ \\ https://orcid.org/0000-0002-4754-9661}

${ }^{1}$ Federal University of Santa Maria, Department of Forestry Science, Santa Maria, Rio Grande do Sul, Brazil; ${ }^{2}$ Federal University of Santa Catarina, Department of Agriculture, Biodiversity and Forests, Curitibanos, Santa Catarina, Brazil;

${ }^{3}$ Federal University of Santa Maria, Department of Biology, Santa Maria, Rio Grande do Sul, Brazil.

Received: 2019.06.11; Accepted: 2020.02.13.

*Correspondence: dilson.bisognin@ufsm.br; Tel.: +55-55-32208900 (D.A.B)

\section{HIGHLIGHTS}

- The anatomy of roots of mate is altered by treatment with indole-butyric acid.

- Anatomical barriers are not an impediment for rooting of mate mini-cuttings.

- Differences in rooting of clones be associated with the presence and distribution of starch.

Abstract: Leaves of mate is one of the main non-timber forest products marketed in South America, which makes establishment of new plantations of great interest. However, vegetative propagation of mate plantlets presents difficulties, which may be associated with the complexity of adventitious root formation. The aims of this study were to anatomically characterize the adventitious roots of mate-clone mini-cuttings and investigate the relationship of phenols and starch with adventitious rooting competence in mini-cuttings treated or not with indole-butyric acid (IBA). The mini-cuttings of four clones were collected at 0,30 , and 60 days of cultivation, fixed in a solution containing $1 \%$ glutaraldehyde and $4 \%$ formaldehyde, pre-infiltrated and infiltrated in (2-hydroxyethyl) methacrylate, and sectioned in a microtome. Ferric chloride and toluidine blue were used to detect phenolic compounds and lugol to identify starch. Adventitious roots formed in minicuttings treated with IBA presented disorganized xylem and phloem and poles irregularly but exhibited sclerenchyma vessel elements and tracheid cells indicating functionality. Differences in the rhizogenic ability of mate clones mini-cuttings were not due to the presence of anatomical barriers or the accumulation of phenolic compounds but be associated with the presence and distribution of starch grains in vegetative propagules.

Keywords: vegetative propagation; indole-butyric acid; anatomical barrier; phenolics; starch. 


\section{INTRODUCTION}

Mate (Ilex paraguariensis A. St.-Hil.) is a tree that belongs to the Aquifoliaceae family which occurs naturally in Southern Brazil, Argentina, and Paraguay [1]. From 1982 to 2005, there was a constant increase in the amount of mate leaves produced in Brazil, leading to a significant decline in its selling price. This scenario has caused several mate producers to substitute their plantations for agricultural products with shorter cycles and annual rent [2]. This led to a reduction of approximately 9000 ha of area harvested with mate in Brazil and, consequently, a decrease in the supply of this raw material to industries between 2005 and 2013 [3]. However, in the last few years, new products manufactured from mate have been introduced in the market [4], which increased the appreciation of this raw material, consequently increasing the selling price [5] and the interest of producers to plant new areas with this crop.

The establishment of new plantations requires plantlets in adequate quantities and of high genetic and morphological qualities. For this, techniques of vegetative propagation of mate has been studied since the 1930s [6] and low rates of adventitious rooting of the propagules has been a concern up to the present day. Adventitious rooting, an essential step in the vegetative propagation of cuttings of perennial plants [7], involves a strong genetic component [8], as observed in clones 10SM07, 06SM17, 06SM15 and 06SM12 of mate, whose rooting rates ranged from 2.5 to $63.4 \%$ [9]. In other forest species, we already know that this variation in the competence for adventitious rooting between clones may be associated with the complexity of the rhizogenic process, both anatomically and physiologically [10].

Anatomically, it is known that the developmental sequence of the adventitious roots is similar to that of the lateral ones. However, the lateral roots are generally derived from the pericyclic layers [11], whereas the adventitious roots are formed from several cell types [12] such as phloem [13], vascular cambium [10], pericycle [14] or callus [15]. In cuttings of adult mate plants, the cambium was considered the key element in root initiation, however, they also initiated from vascular mass formed in the calluses [16]. This makes the anatomy of the adventitious rooting process variable and still little understood [12], despite its importance when seeking to maximize rhizogenic rates.

Among the anatomical characteristics that influence the success of adventitious rooting, anatomical barriers have received much interest since the 1960s [17,18]. The anatomical barrier is originated by the continuous sclerification of the phloem and is considered by some authors one of the main obstacles to the formation of adventitious roots in vegetative propagules $[19,20]$. However, it is important to consider that this arrangement and the presence of this tissue are not characteristics common to all species. The presence of a continuous band of sclerenchyma cells without visible disruption was observed in holly, Ilex aquifolium $\mathrm{L}$. also Aquifoliaceae [21], and in bark residues from mate tree harvests [22]. However, there are no reports in the literature on vegetative propagules of mate regarding either the presence or absence of this anatomical structure.

The formation of adventitious roots is also dependent on physiological factors, such as plant hormones (especially auxins), phenolic compounds and carbohydrates. Auxin is usually synthesized in the stem tips and young leaves and then transported to action sites [23]. In some species, the endogenous levels of auxins are not sufficient to promote rooting, necessitating supplementation of the hormonal content through the application of phytoregulators [24]. In mate, studies have emphasized the need or not for the application of indole-butyric acid (IBA) in the rooting of vegetative propagules [25,9]; however, information regarding the anatomical characterization of adventitious roots after treatment with IBA are scarce.

Similar to auxins, phenolic compounds influence rhizogenesis, but the results depend on the number of $\mathrm{OH}$ groups and by their position in the aromatic ring [26]. Monophenols stimulate while polyphenols inhibit the oxidation of indole-acetic acid (IAA), respectively minimizing and maximizing the rooting of vegetative propagules [27]. Carbohydrates, especially starch, are also considered important sources for adventitious rooting, both structurally and in terms of energy $[7,28]$. Vegetative propagules with high carbohydrate contents generally present better rhizogenic responses [15].

Considering the importance of vegetative propagation for the production of high quality mate plantlets in adequate quantities and taking into account that the competence of mini-cuttings for adventitious rooting depends on the genetic component and may be associated with anatomical and physiological characteristics, this study aims to anatomically characterize the adventitious roots, the presence of phenolic compounds and starch, and their relationship with adventitious rooting competence of mini-cuttings of different mate clones, treated with or without IBA. 


\section{MATERIAL AND METHODS}

\section{Plant material}

Mini-stumps of mate clones 06SM17, 06SM15 and 06SM12, derived from in vitro germination of zygotic embryos, and clone 10SM07, derived from cuttings of epicormic shoots of an approximately 20-year-old plant [9], were established in a mini-clonal hedge in the greenhouse at the Center for Plant Improvement and Vegetative Propagation, Federal University of Santa Maria (UFSM), in the city of Santa Maria, Rio Grande do Sul, Brazil. Exsiccates of branches of mini-stumps were deposited in the Herbarium of the Department of Forest Sciences at UFSM, under number 7521.

The shoots were collected in July 2014 and mini-cuttings were produced with one bud and approximately $2.0 \mathrm{~cm}$ in length, and one leaf reduced to $50 \%$ of its original area. The mini-cuttings were treated or not with a hydroalcoholic solution of indole-butyric acid (IBA) at a concentration of $2000 \mathrm{mg} \mathrm{L}^{-1}$ and cultivated in polystyrene trays with 128 wells, containing pine bark-based commercial substrate, vermiculite and coarse sand $(1: 1: 1 \mathrm{v} / \mathrm{v} / \mathrm{v})$ and kept in a wet chamber with relative air humidity of approximately $85 \%$ provided by automated nebulization 8 times a day for 1 minute [9].

\section{Anatomical analysis}

At the beginning of the experiment ( 0 days) and after 30 and 60 days of cultivation in the wet chamber, three mini-cuttings of each treatment (four clones and two IBA treatments) were collected for anatomical analysis, totaling 72 mini-cuttings reviewed during the trial period. The mini-cuttings were fixed in a solution containing $1 \%$ glutaraldehyde and $4 \%$ formaldehyde in $0.1 \mathrm{M}$ sodium phosphate buffer, $\mathrm{pH} 7.2$ [29, 30], wash in the same buffer, wash in distilled water, and dehydrated using an ascending ethyl alcohol series $(10 \%$, $30 \%, 50 \%$, and $70 \%$ ) for $10 \mathrm{~min}$ at each concentration, followed by $90 \%$ ethyl alcohol for 15 min and $100 \%$ ethyl alcohol for another 15 min [31].

The material was pre-infiltrated in Leica ${ }^{\circledR}$ (2-hydroxyethyl) methacrylate (HEMA) and a $99.6 \%$ ethanol solution $(1: 1 \mathrm{v} / \mathrm{v})$ for $12 \mathrm{~h}$, followed by infiltration in HEMA for approximately $4 \mathrm{~h}$ and embedding in a Teflon holder until polymerization was complete [32]. The samples were sectioned at a thickness of 3 and $5 \mu \mathrm{m}$ at the region of the stem and adventitious roots of the mini-cuttings, using a RM2245 Leica rotary microtome. The histological slides were stained with Toluidine Blue in a $0.05 \%$ sodium benzoate buffer, $\mathrm{pH} 4.4$ [33], Astra Blue and Basic Fuchsin [34,35]. Ferric chloride [36] and Toluidine Blue [37] were used to identify phenolic compounds in fresh material after hand sectioning, and the lugol solution was used to detect starch [36]. Callose was detected with aniline blue [38] and viewed with epifluorescence optics using a Zeiss ${ }^{\mathrm{TM}}$ Axio Imager A2 microscope. In addition, the callus region of the mini-cuttings was macerated [39 modified from $40]$ to isolate small groups and/or individual tracheal and fibrous elements.

Photographic documentation and analysis in bright field and polarized light were performed using a Leica® DM 2000 microscope with DFC295 image capture system and LAZ 4.0 software. Analysis under Differential Interference Contrast (DIC) and fluorescence were performed using a Zeiss Axiolmager A2 microscope equipped with a filter set to 02 (excitation G 365, beam splitter FT 395, emission LP 420), a Zeiss MCr digital capture system, and ZEN (Zeiss ${ }^{\mathrm{TM}}$ ) software. Adobe ${ }^{\circledR P h o t o s h o p}{ }^{\circledR}$ was used to process the images.

\section{RESULTS}

\section{Anatomy after 0 days of cultivation}

The anatomical structures of the mate mini-cuttings from clones 06SM17, 06SM15, 06SM12 and 10SM07 were similar in transverse sections at the beginning of the experiment (before cultivation in wet chamber). Regardless of the clone, the mini-cuttings presented a single layered epidermis, followed by a predominantly parenchymatous cortical region (Figures 1a, 1b). In the cortical region, the outer portion was formed by chlorenchyma, whose cells were arranged compactly and presented a large amount of phenolic compounds, followed by parenchyma, whose cells presented a reduced amount of chloroplasts and little or no presence of phenolic compounds. The internal edge of the cortical region was defined by the endoderm, whose cells were arranged compactly (Figure 1a) due to non-differentiation of Caspary striae, which is common for stem endoderm. Internally to the endoderm, in the perivascular fibers, there was a continuous layer of fibers and stone cells interspersed, which presented variable thickness between one and six layers of these elements of sclerenchyma (Figures 1a, 1b). Beyond the perivascular fibers, there were regions of primary phloem, secondary phloem, vascular cambium, secondary xylem (Figure 1a), primary xylem, and 
medulla. The vascular cambium contained cells that individually present average $228 \mu \mathrm{m}$ in length, besides other cytological characteristics, as a developed vacuole and a central nucleus (Fig. 1b). The parenchymatous or already sclerified medullar region presented cells with grains of starch (Figures 1c, 1d).
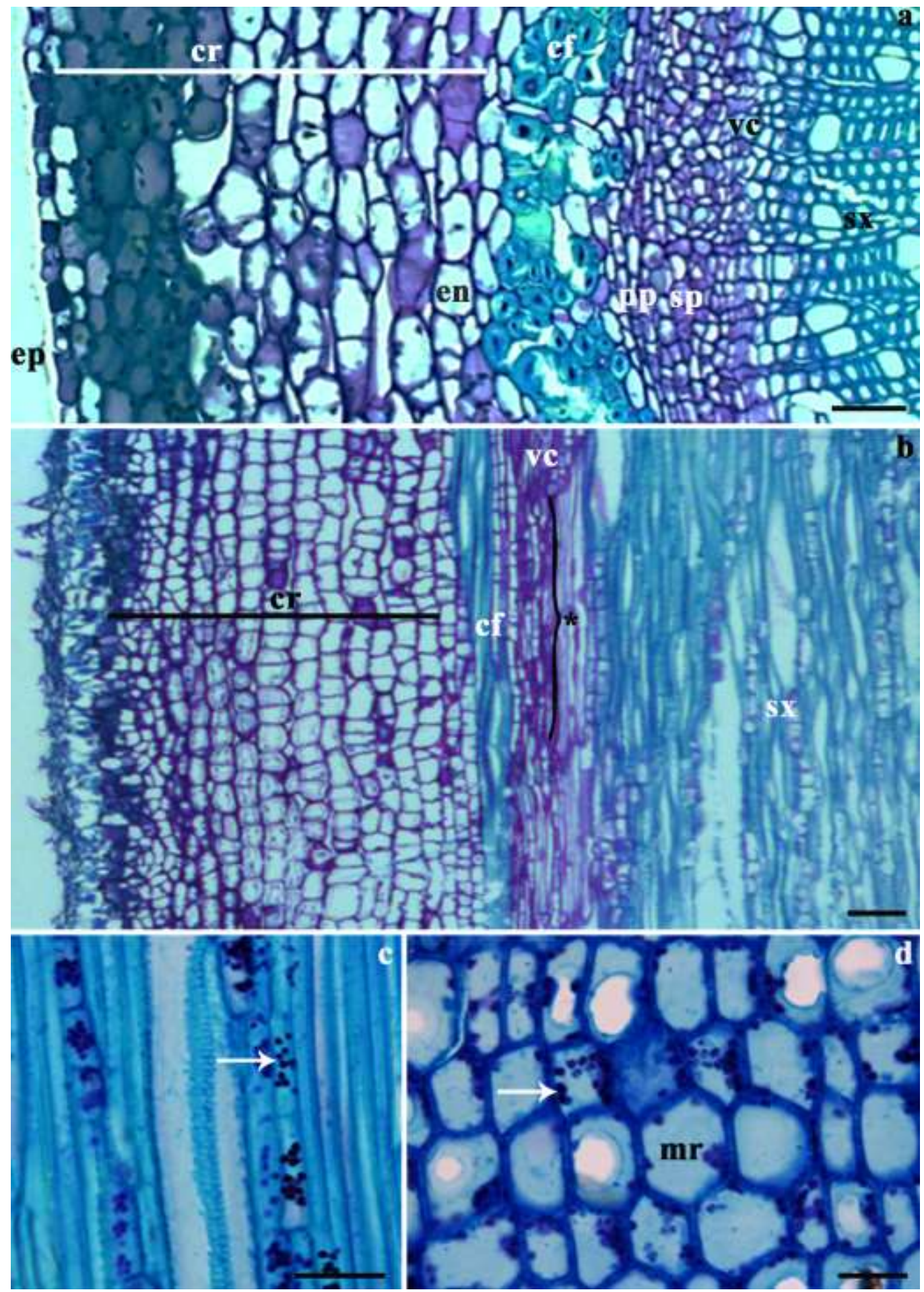

Figure 1. Bright field microscopy of mini-cuttings of the mate clone $10 \mathrm{SM} 07$ treated with $2000 \mathrm{mg} \mathrm{L}^{-1}$ of IBA at 0 days of cultivation. (a) Transverse section, with details of the epidermis (ep), endoderm (en), and cortical region (cr) arranged compactly, continuous layer of fibers (cf), primary phloem (pp), secondary phloem (sp), vascular cambium (vc), and secondary xylem (sx). (b) Longitudinal section, with details of secondary xylem (sx), continuous layer of fibers and stone cells interspersed (cf), cortical region (cr), and the length of the vascular cambium cells (asterisk). (c) Longitudinal section, with starch grains (arrow). (d) Transverse section, detailing the medullary region (mr) with starch grains (arrow). Scale: $A=100 \mu \mathrm{m} ; B=500 \mu \mathrm{m} ; C$ and $D=50 \mu \mathrm{m}$. 


\section{Anatomy after $\mathbf{3 0}$ days of cultivation}

There were anatomical responses to the cultivation in the four clones studied at 30 days in the wet chamber, which were manifested at up to $4-5 \mathrm{~mm}$ in height in the secondary vascular tissues originating at the base of the mini-cutting. This response was, therefore, progressive and acropetal, resulting in an increase in the diameter of the mini-cuttings in the cortical region and consequently in their conical shape (Figures 2a, $2 \mathrm{~b})$. Neoformed xylem and phloem, making up the tissues with calluses, correspond to vascular connections of the adventitious roots and are observed at the basal portion of the mate mini-cuttings of the four clones (Figure 2b).

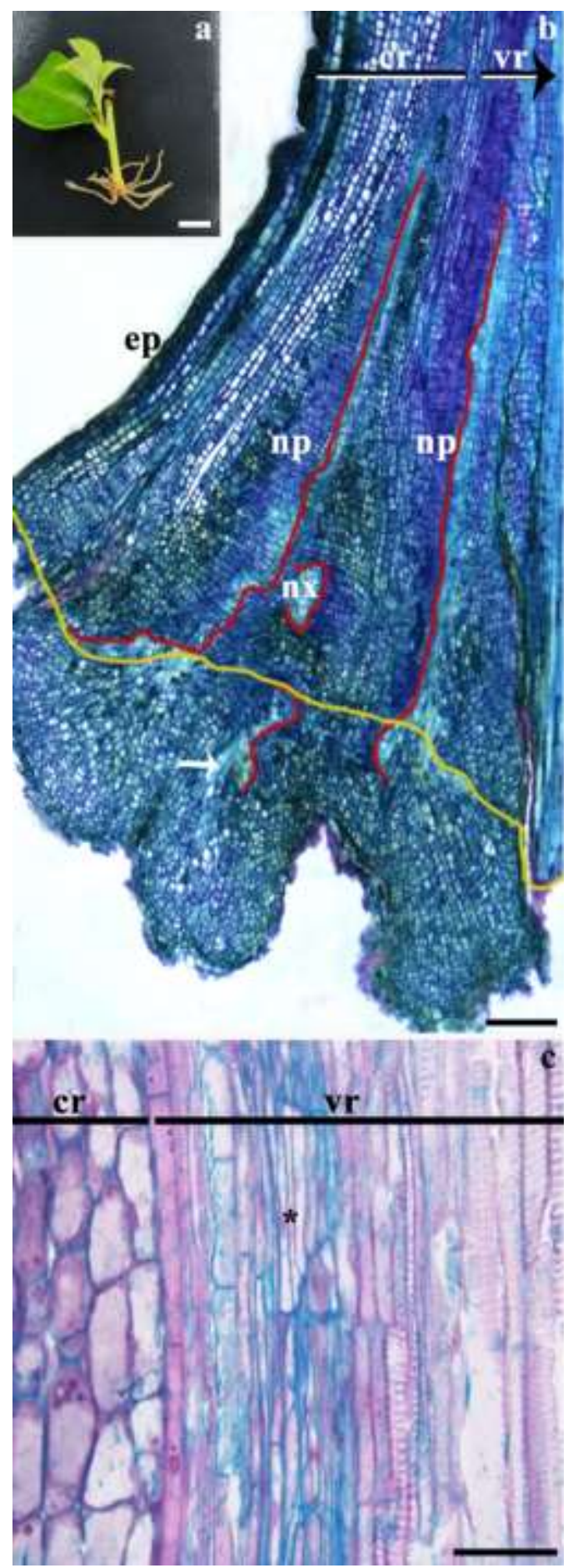

Figure 2. Rooted mini-cutting of mate clone 06SM15 not treated with IBA at 30 days of cultivation in the wet chamber. (a) Macroscopic aspects of adventitious rooting. (b) Longitudinal section of rooted mini-cutting, detailing the epidermis (ep), cortical region (cr), vascular region (vr), and new proliferated tissues (red lines), such as neoformed xylem (nx) and phloem (np) with vascular connection with the adventitious roots (white arrow) and tissues with calluses at the base of the vegetative propagule (yellow line). (c) Longitudinal section of rooted mini-cutting, detailing neoformed vascular cambium cells (asterisk). Scale: $A=5 \mathrm{~mm} ; B=500 \mu \mathrm{m} ; C=50 \mu \mathrm{m}$. 
In addition to the cellular proliferation, there were also alterations in the vascular cambium activity and cell structure, which after a sequence of transversal divisions presented reduction in the length of the cambial cells, ranging from 34 to $128 \mu \mathrm{m}$ (Figure $2 \mathrm{c}$ ). These changes in the vascular cambium resulted in a shortening of the initial neoformed xylem and phloem cells. Proliferation of parenchyma cells from the primary phloem were also observed. Parenchyma cells of the cortical region also reacted to the cultivation, by proliferation of new parenchyma tissues and conductors (Figure 3a).

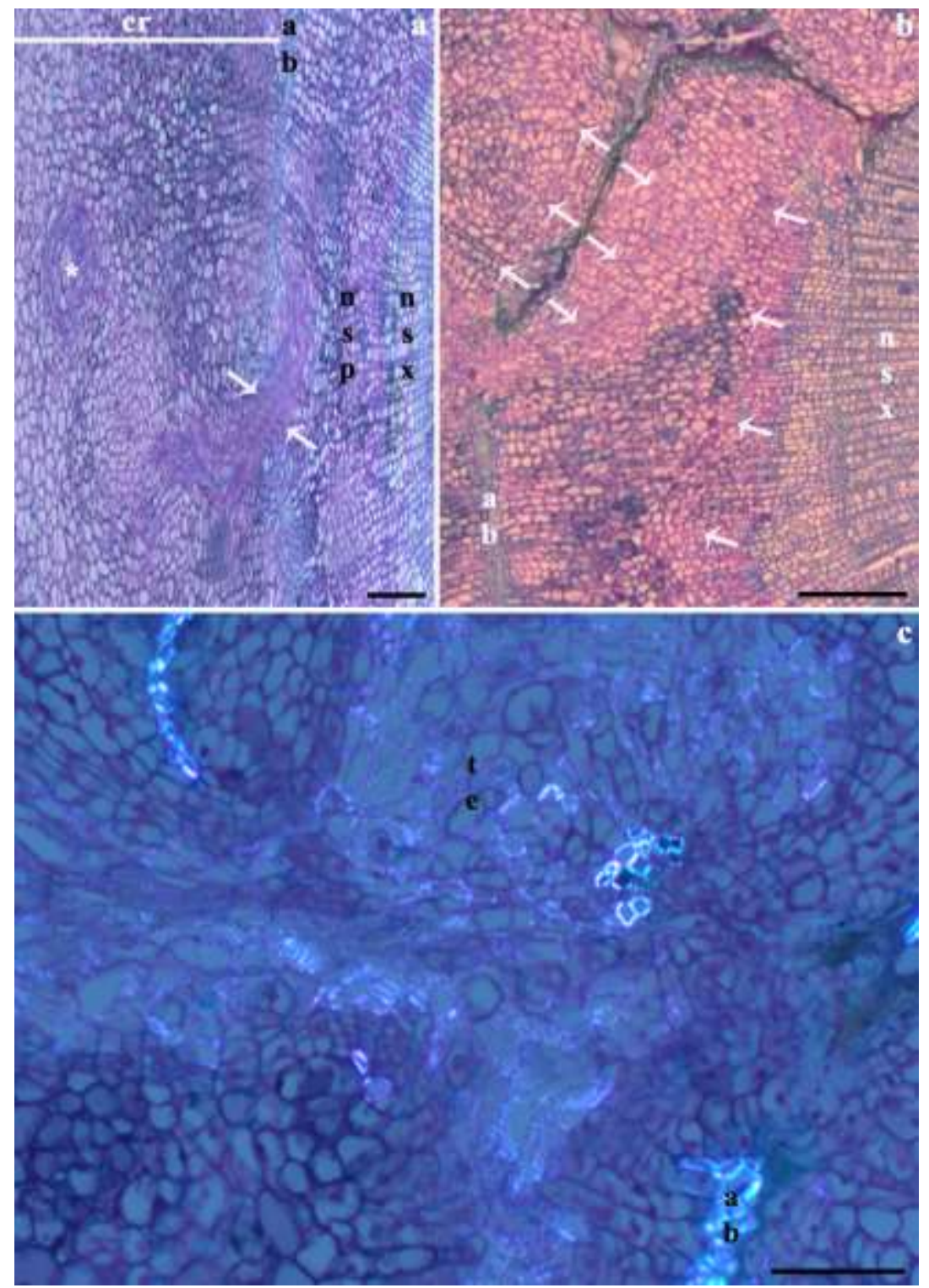

Figure 3. Transverse sections of mini-cuttings of mate clone $10 \mathrm{SM} 07$ not treated with IBA, in bright field (a, b) and polarized light (c) at 30 days of cultivation. (a) Cortical region (cr), neoformed secondary phloem (nsp), neoformed secondary xylem (nsx), and vascular grouping of curved cells (asterisk), arrows indicate the discontinuity of the anatomical barrier (ab). (b) Detail of the discontinuity of the anatomical barrier (ab) and the neoformed secondary xylem (nsx), arrows indicate regions of proliferation of new tissues. (c) Detail of the tracheoidal elements (te) and anatomical barrier (ab). Scale: $A=200 \mu \mathrm{m}, \mathrm{B}=100 \mu \mathrm{m}$ and $\mathrm{C}=200 \mu \mathrm{m}$.

The increased diameter of the mini-cuttings, resulting from the proliferation of tissues with calluses, generated the discontinuity of fiber layers, also referred to as anatomical barriers, filling the respective spaces with neoformed parenchyma tissues (Figures 3a, 3b, 3c), regardless of the clone and treatment with IBA, at 30 and 60 days of cultivation. In addition, vascular tissues were found to differentiate from the neoformed tissues of cells of the inner portion of the cortical region (Figure 3b). The origin of such vascular elements was neoformed parenchyma cells. In some samples of the 06SM17 clone, a small amount of neoformed tissue was observed outside of the anatomical barrier. 


\section{Anatomy after 60 days of cultivation}

Regardless of treatment with auxin and of the clone studied, adventitious roots formed from tissues with calluses. However, it was verified that the mini-cuttings of mate treated with $2000 \mathrm{mg} \mathrm{L}^{-1}$ of IBA presented roots with alterations in the structure of the central cylinder, mainly in relation to the disorganized xylem and phloem, which develops next to the pericycle and has its poles distributed irregularly (Figure 4a).

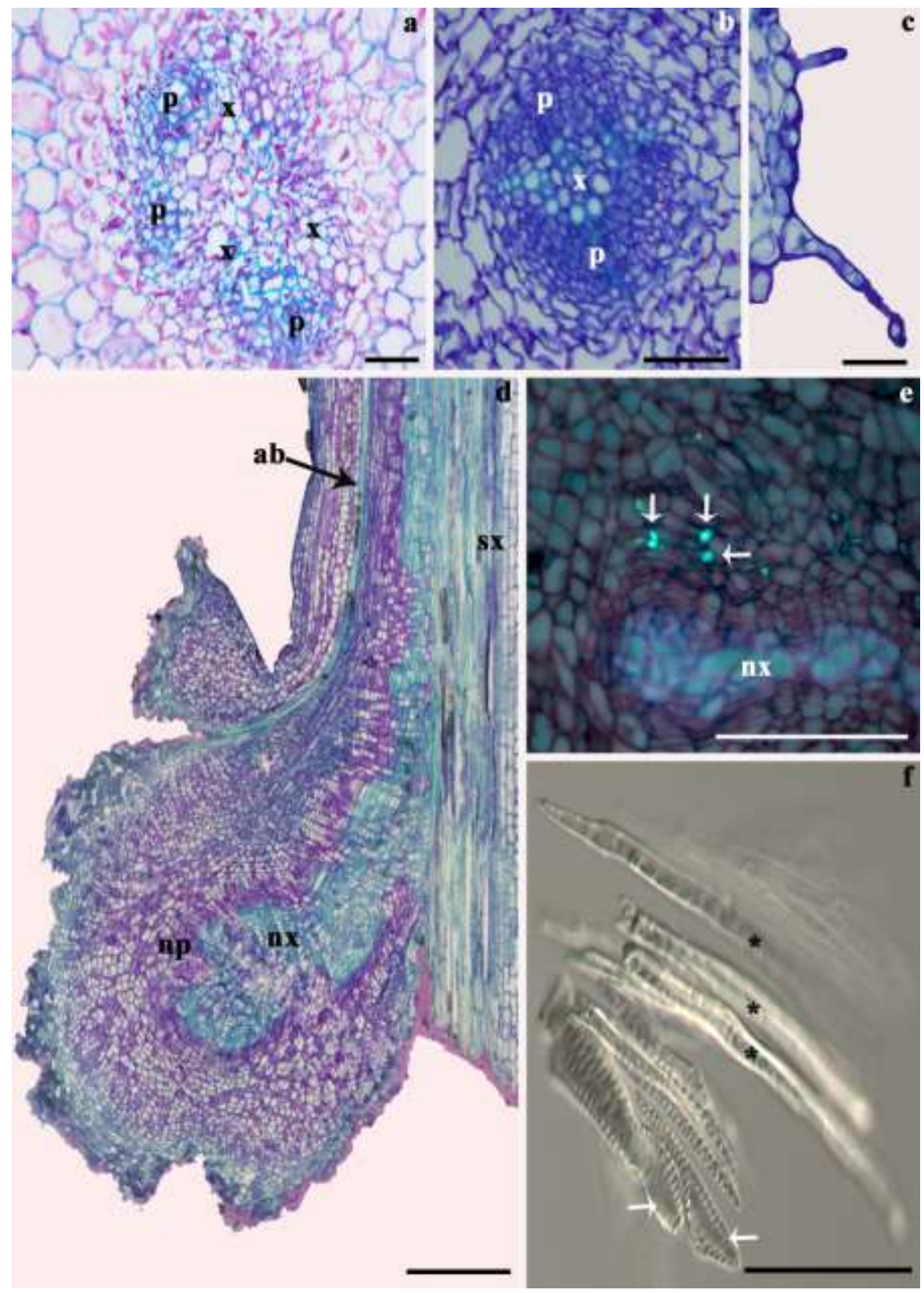

Figure 4. Transverse (a, b, c, e) and longitudinal (d) sections of adventitious roots formed in mini-cuttings of the mate clone $06 \mathrm{SM} 15$ in bright field (a, b, c, and d), fluorescence (e) and DIC (f) at 60 days of cultivation. (a) Root formed in mini-cutting treated with $2000 \mathrm{mg} \mathrm{L}^{-1}$ of IBA, which presented xylem (x) and phloem (p) disorganized in the central cylinder. (b) Diarch adventitious root formed in the mini-cutting not treated with IBA, with organized pattern of both xylem (x) and phloem (p). (c) Detail of the root hair zone formed in mini-cutting not treated with IBA. (d) General aspect of vascular connection that vascularizes the adventitious roots. (e) Detail of the tissues with callose. Fluorescence indicates accumulation of callose in sieve plates (arrows). (f) Vessel elements present in tissues with calluses, which appear as plates of simple perforation (arrows) and fiber-tracheids (asterisk). Scale: $a, b, c$ and $e=100 \mu \mathrm{m} ; d=500 \mu \mathrm{m} ; f=50 \mu \mathrm{m}$.

In the material not treated with IBA, the central cylinder presented vascular organization similar to that expected for primary roots in angiosperms, with primary phloem strands alternating with the primary xylem strands (Figure 4b), highlighting the presence of absorptive trichomes in the root hair zone (Figure 4c). Regardless of treatment with IBA, the adventitious roots had robust connections with the main vascular tissue 
of mini-cuttings (Figures $2 b, 4 d$ ), because they have a profuse arrangement of sclerified tissues, including vessel elements, sclerenchyma elements, and tracheoidal elements (Figure 4d), which are differentiated within calluses.

Tissues with calluses observed in mini-cuttings of mate are made up basically of vascular tissues with presence of xylematic tracheoidal elements, fiber-tracheids, vessel elements with plates of simple or scalariform perforation, and sieve-tube elements with sieve plates containing callose (Figures $4 \mathrm{e}, 4 \mathrm{f}$ ). The neoformed vascular tissues at the periphery of the vegetative propagules presented a general spherical arrangement due to the large degree of curvature of the cells or the conducting elements (Figure $4 \mathrm{f}$ ). Accompanying the tracheoidal elements, there are elements similar to fiber-tracheids, owing to the clear presence of bordered pits, parietal thickening and lignification, and the absence of perforation plates, besides their relatively reduced length (Figure $4 \mathrm{f}$ ).

\section{Phenols and starch}

The test with ferric chloride solution revealed the presence of phenolic compounds in the epidermis of the mini-cuttings of the four clones of mate at the beginning of the experiment. At 60 days of cultivation in a wet chamber, the presence of these compounds was also observed in the cortex and the cells with calluses, regardless of the clone studied and treatment with IBA. It should be noted that ferric chloride, although used as a marker for non-structural phenolic compounds, did not indicate such compounds (Figure 5a), while toluidine blue also indicated compounds accumulated in the cytoplasm (not structural) (Figure 5b), when comparing to the same regions at the beginning and at 30 and 60 days of cultivation in the wet chamber.

The lugol reagent showed the presence of starch in the cortical and medullar region, in the primary and secondary xylem, including rays and endoderm of mate mini-cuttings, regardless of the clone and treatment with IBA, at the beginning of the experiment (Figures 5c,5d). However, although quantitative analysis of starch was not performed, the microscopy analysis showed smaller amounts or absence of starch grains in the mini-cuttings of clone $10 \mathrm{SM} 07$ (Figures $5 \mathrm{c}, 5 \mathrm{e}, 5 \mathrm{~g}$ ) when compared to the mini-cuttings of clone $06 \mathrm{SM} 15$ (Figures $5 \mathrm{~d}, 5 \mathrm{f}, 5 \mathrm{~h}$ ), mainly at 60 days of cultivation in the wet chamber. 

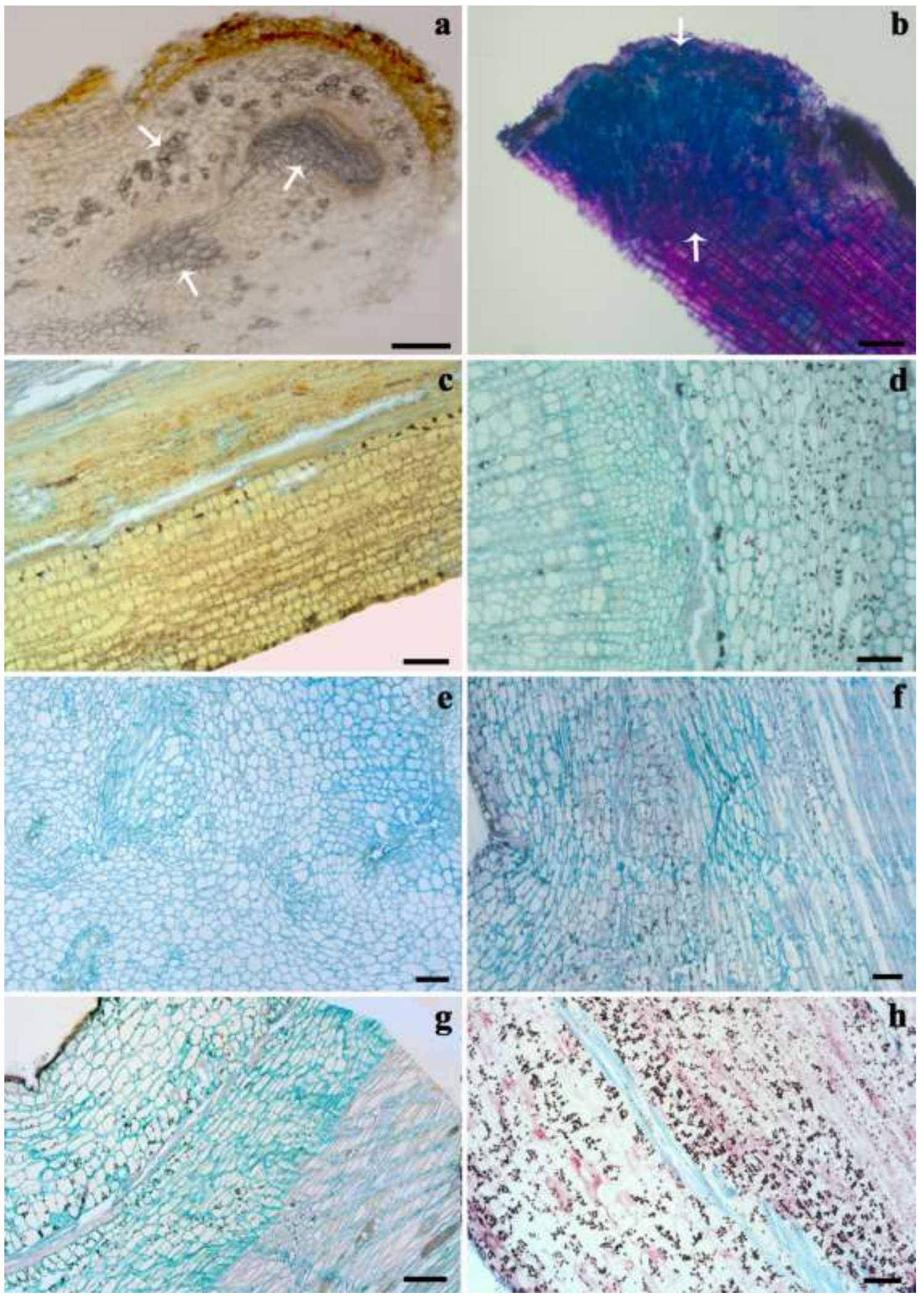

g

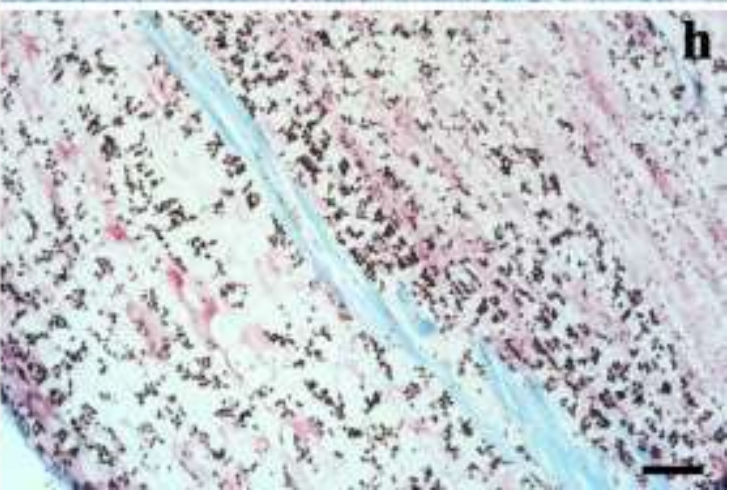

Figure 5. Identification and localization of phenolic compounds and starch. (a) Ferric Chloride and (b) Toluidine Blue in longitudinal sections, hand-cut from fresh material of mate mini-cuttings of clone 10SM07 not treated with IBA, at 60 days of cultivation in a wet chamber. Detection of the starch grains using lugol solution in transverse sections of minicuttings of clone 10SM07 (c, e and g) and 06SM15 (d, f and h) not treated with IBA at 0 (c and d), 30 (e and f) and 60 days $(g$ and $h$ ) of cultivation in a wet chamber. Scale: $a, b, c, d$ and $f=50 \mu \mathrm{m} ; \mathrm{e}=20 \mu \mathrm{m} ; \mathrm{g}$ and $\mathrm{h}=100 \mu \mathrm{m}$. 


\section{DISCUSSION}

\section{Anatomical analysis}

The anatomical analysis of mini-cuttings stems of four clones of mate showed similarities, regardless of treatment with IBA, both at the beginning and at 30 and 60 days of cultivation. This shows that the structural aspects linked to differentiation of cells and tissues and development patterns were similar among the clones studied. The anatomical characteristics observed in this study were reported in cuttings from adult plants of mate [16], as well as in other taxa of the Aquifoliaceae, such as holly [21]. Disorganization of the central cylinder was observed in the adventitious roots of mini-cuttings treated with auxins, which could be related to the capacity of this phytoregulator to promote cell proliferation [15]. Similar changes were observed in the structure of the central cylinder of micro-cuttings of Gomphrena macrocephala St.-Hil., when they were treated with $10 \mathrm{mg} \mathrm{L}^{-1}$ of IBA [41].

In the present study, anatomical analysis of the mini-cuttings of the four clones of mate showed the presence of a discontinuous sclerenchymal barrier, due to the proliferation of tissues with calluses and the filling of these spaces with parenchymal tissue, which was not an impediment to the rhizogenic process of this species. The difficulty of vegetative propagules to form adventitious roots may be related to the anatomical structure of the primary phloem, which presents a continuous ring made up of lignified elements that mechanically block the protrusion of adventitious roots through the sclerenchyma [17]. This hypothesis was questioned and rejected by Sachs and coauthors [18], who observed that in cuttings of olive (Olea europaea L.), pear (Pyrus spp.) and cherry (Prunus spp.) there was no relation between the continuity of this ring of sclerenchyma and rooting competence, since these differences may be related to the ability of the cells that initiate the root system to expand and proliferate and, subsequently, to organize the adventitious root primordia [18]. In vassourão-branco (Piptocarpha angustifolia Dusén) cuttings, rupture of the sclerenchyma was also reported and was not considered a mechanical barrier to the emergence of adventitious roots [42]. In addition, the sclerenchymal tissue formed in the mini-cuttings of mate originates from the pericycle and presented a circumferential aspect, which, according to Sachs and coauthors [18], can only be considered an anatomical barrier if it formed a transverse plate, which has not been shown to occur during healing process.

In species or clones with a discontinuous sclerified layer, adventitious rooting may occur by direct organogenesis of the cell types established in the stem tissues, as well as by indirect organogenesis, where root formation is preceded by the proliferation of tissue with calluses following mechanical damage [15]. In the mini-cuttings of the four clones of mate, treated or not with IBA, the root system was developed in the periphery of the tissues with calluses. Similar results were also reported in cuttings of six genotypes of Acacia baileyana $\mathrm{F}$. Muell. treated with 0,1000 and $5000 \mathrm{mg} \mathrm{L}^{-1}$ of IBA, where the development of callus preceded and led to the initiation of roots in the vegetative propagules [43].

The anatomy of the rhizogenic process in mate was studied by Iritani and coauthors [16], who reported the occurrence of both direct and indirect organogenesis. These authors used cuttings of 40 -year-old adult trees as vegetative propagules, while the present study analyzed mini-cuttings of possibly rejuvenated clones, which may explain the different responses. It is known that modifications in the source of adventitious roots may occur in the presence of auxins [41], since callus induction is dependent on the levels of this phytoregulator. Vegetative propagules with a higher degree of maturation have a lower endogenous content of auxins [44], which probably resulted in decreased proliferation of the tissues with calluses in the cuttings of adult trees of mate, leading to direct rooting, which is not dependent on callus formation.

In this study, it was possible to observe the structural characteristics linked to the conducting elements in callus tissue and adventitious roots of mini-cuttings of different mate clones. Among the conducting elements observed stands out the vessel elements and sieve-tube elements, responsible for transporting water and elaborated sap, so that it probably occurred transpiration process, nutrient cycling and distribution of photoassimilates in these vegetative propagules during cultivation in the wet rooting chamber. These physiological processes occur when there is a satisfactory photosynthetic area in the vegetative propagule, among other factors [15], in this case provided by the leaf presence reduced by $50 \%$ of its original area in the mini-cuttings.

As for the anatomical characteristics of the rhizogenic process, there was an expressive vascular connection considered significant between the roots and the secondary vascular tissues, and the presence of absorptive trichomes in the adventitious roots of mini-cuttings of mate treated or not with IBA. Thus, even if the adventitious roots present changes in the central cylinder when originating from mini-cuttings treated with auxins, they present features that indicate root system functionality equal to that of propagules not 
treated with this auxin. Similar results were observed in roots formed in cuttings of adult trees of mate, which were also considered functional when treated with 3000 and $5000 \mathrm{mg} \mathrm{L}^{-1}$ of IBA or IAA [16].

The functionality of adventitious roots formed in mate mini-cuttings from clones 06SM17, 06SM15, 06SM12 and 10SM07 was confirmed in studies by Pimentel and coauthors [45], which presented satisfactory survival and morphophysiological quality of plantlets, regardless of treatment with 0 or $2000 \mathrm{mg} \mathrm{L}^{-1}$ of IBA during adventitious rooting. However, it should be pointed out that even though the root system formed in mini-cuttings treated with IBA presents functionality and allows the production of plantlets with a quality similar to that of mini-cuttings not treated with auxin, use of this phytoregulator is not recommended, since it does not maximize adventitious rooting [9] increasing the labor and costs involved in the process of plantlet production.

\section{Phenols and starch}

The presence of phenolic compounds may be related to increased adventitious rooting, as observed in cuttings of cherry tree (Prunus sp.) [46] or minimized rhizogenic potential reported in olive cuttings (Olea europaea L.) [28]. It has been claimed that when there is maximization of the rhizogenic capacity, it is the polyphenols that protect the IAA from oxidation [47] whereas when there is a reduction in the rooting rate, it is assumed that this is due to monophenols, whose compounds cause the degradation of IAA. Phenolic compounds were present in the epidermis, cortex and tissues with calluses in the four clones of mate studied, showing that the presence or absence of this compound does not explain the low competence for rooting in clone 10SM07 when compared to the others, as noted by Pimentel and coauthors [9]. Through microscopy analysis, apparently only the amounts of total phenolic compounds are similar, i.e. microscopy does not provide a quantitative inference, nor does it allow discrimination between phenolic categories, mainly monophenols and polyphenols. Therefore, in future studies, it is necessary to elucidate the chemical composition of these phenolic compounds through specific tests, which will allow confirmation as to whether their composition influences the variation in rhizogenic ability of mate clones.

In this study, the mini-cuttings of the clone 10SM07, which presented a lower percentage of rooting [9] apparently presented a lower quantity and distribution of starch grains, when compared to the other clones. The formation of adventitious roots can be influenced by carbohydrates; however, there is no consensus regarding the role played during the rhizogenic process, whose presence is indirectly shown by the presence of starch [28]. A number of authors have reported the importance of carbohydrates in adventitious rooting $[7,28,15]$, while others have reported no relation between the presence of carbohydrates and the rhizogenic capacity observed in certain species or cultivars, such as vassourão-branco [42] and cancorosa [14].

Thus, the results of this study show that the differences in the rhizogenic ability from mini-cuttings of the four clones of mate are not due to the presence of anatomical barrier (sclerified layer) and accumulation of phenolic compounds. However, the lower accumulation of starch in the vegetative propagules of clone 10SM07 may explain the low adventitious rooting rate in its mini-cuttings. Further studies to analyze amylogenesis and sugars derived from amylolysis, such as glucose, sucrose and fructose, which are also considered stimulators of adventitious roots, are necessary to elucidate the metabolic responses that occur in mini-cuttings of mate during the rhizogenic process.

\section{CONCLUSION}

The adventitious roots formed in the mini-cuttings of four mate clones treated with IBA present disorganized xylem poles but maintain functionality. The original anatomical barrier was not an impediment to the rooting process of the mini-cuttings. Differences in the rhizogenic competence of mate clones were not due to the accumulation of phenolic compounds, but they were associated with the presence and distribution of starch grains in vegetative propagules this specie.

Acknowledgments: The authors are grateful to the Brazilian Council for the Improvement of Higher Education (CAPES) for scholarships.

Conflicts of Interest: The authors declare no conflict of interest. 


\section{REFERENCES}

1. Heck Cl, Mejia EG. Yerba Mate Tea (Ilex paraguariensis), a comprehensive review on chemistry, health implications, and technological considerations. J Food Sci. 2007 Nov;72:138-151.

2. Almeida NA, Santos AJ, Silva JCGL, Bittencourt AM. Análise do mercado dos principais produtos não madeiráveis do estado do Paraná (Analysis of the market of the main non timber forest products of Parana State). Floresta. 2009 Oct;39(4):753-763.

3. Food and agriculture organization of the United Nations. Faostat 2018 [Internet]; [updated 2016 Dez; cited 2019 Mar]. Available from: http://www.fao.org/faostat/en/\#data/QC.

4. Dallabrida VR, Dumke Cl, Molz S, Furini V, Giacomelli MBO. Com erva-mate não se faz só chimarrão! Situação atual e perspectivas de inovação no setor ervateiro do planalto norte catarinense. (With yerb mate not just to make chimarrão! Current situation and innovation perspectives on mate sector of north plateau catarinense). Rev Des Reg em foco. 2016 Jul;6(2):247-273.

5. Zanin V, Meyer LG. Evolução da margem de comercialização da erva mate no Rio Grande do Sul. (Evolution of commercialization of the Ilex paraguariensis in Rio Grande do Sul). Rev iPecege. 2018 Mar;4(1):7-18.

6. Prat Kricun SD. Propagación vegetativa de plantas adultas de Yerba mate. In: Winge H, editor. Erva-mate: biologia e cultura no Cone Sul. Porto Alegre: Editora UFRGS; 1995. p. 137-150.

7. Corrêa LR, Paim DC, Schwambach J, Fett-Neto AG. Carbohydrates as regulatory factors on the rooting of Eucalyptus saligna Smith and Eucalyptus globulus Labill. Plant Growth Regul. 2005 Jan;45:63-73.

8. Mokotedi MEO, Watt MP, Pammenter NW, Blakeway FC. In vitro rooting and subsequent survival of two clones of a cold-tolerant Eucalyptus grandis x E. nitens hybrid. HortScience. 2000 Oct;35(6):1163-1165.

9. Pimentel N, Lencina KH, Kielse P, Rodrigues MB, Somavilla TM, Bisognin DA. Produtividade de minicepas e enraizamento de miniestacas de clones de erva-mate (Productivity of mini-stumps and rooting of mini-cuttings of erva-mate clones). Ciência Florestal. 2019 Jun;29(2):559-570.

10. Goulart PB, Xavier A, larema L, Otoni WC. Morfoanatomia da rizogênese adventícia em miniestacas de Eucalyptus grandis $\mathrm{x}$ Eucalyptus urophylla (Morpho-anatomic of adventitious rhizogenesis in mini-cuttings of Eucalyptus grandis $x$ Eucalyptus urophylla). Ciência Florestal. 2014 Jul;24(3):521-532.

11. Li SW, Xue L, Xu S, Feng H, An L. Mediators, genes and signaling in adventitious rooting. Bot Rev. 2009 Jun;75:230-247.

12. Bellini C, Pacurar DI, Perrone I. Adventitious roots and lateral roots: similarities and differences. Annu Rev Plant Biol. 2014 Feb;65:639-666.

13. Mayer JLS, Cardoso NA, Cuquel F, Bona C. Formação de raízes em estacas de duas espécies de Calliandra (Leguminosae-Mimosoideae) (Root formation in cuttings of two species of Calliandra (LeguminosaeMimosoideae). Rodriguésia. 2008;59(3):487-495.

14. Lima DM, Biasi LA, Zanette F, Zuffellato-Ribas KC, Bona C, Mayer JLS. Capacidade de enraizamento de estacas de Maytenus muelleri Schwacke com a aplicação de ácido indolbutírico relacionada aos aspectos anatômicos (Rooting capacity of Maytenus muelleri Schwacke cuttings with indolebutyric acid application related to anatomical aspects). Rev Bras PI Med. 2011;13(4):422-438.

15. Hartmann HT, Kester DE, Davies RT, Geneve RL. Plant propagation: principles and practices. 8 ed. New Jersey: Prentice Hall; 2011. 915 p.

16. Iritani C, Soares RV, Gomes AV. Aspectos morfológicos da aplicação de reguladores do crescimento nas estacas de Ilex paraguariensis St. Hilaire (Morphological aspects of the action of auxins on leafy cuttings of Ilex paraguariensis St. Hilaire). Acta Biol Parana. 1986 Dec;15(1,2,3,4):21-46.

17. Beakbane AB. Structure of the plant stem in relation to adventitious rooting. Nature. 1961 Dec;192(4806):954-955.

18. Sachs RM, Loreti F, De Bie J. Plant rooting studies indicate sclerenchyma tissue is not a restricting factor. California Agriculture. 1964 Sep;18(9):4-5.

19. Mayer JLS, Biasi LA, Bona C. Capacidade de enraizamento de estacas de quatro cultivares de Vitis L. (Vitaceae) relacionada com os aspectos anatômicos (Rooting ability of four Vitis L. (Vitaceae) cultivar cuttings related to anatomy). Acta Bot Bras. 2006;20(3):563-568.

20. Bryant PH, Trueman SJ. Stem anatomy and adventitious root formation in cuttings of Angophora, Corymbia and Eucalyptus. Forests. 2015;6:1227-1238.

21. Edwards RA, Thomas MB. Observations on physical barriers to root formation in cuttings. Plant propagator. 1980;26(2):6-8.

22. Pagliosa CM, Simas KN, Amboni RDMC, Murakami ANN, Petkowicz CLO, Medeiros JD, et al. Characterization of the bark from residues from mate tree harvesting (Ilex paraguariensis St. Hil.). Ind Crops Prod. 2010 Nov;32:428433. 
23. Ljung K, Bhalerao RP, Sandberg G. Sites and homeostatic control of auxin biosynthesis in Arabidopsis during vegetative growth. Plant J. 2001 Nov;28(4):465-474.

24. Pop TI, Pamfil D, Bellini C. Auxin control in the formation of adventitious roots. Not Bot Horti Agrobot Cluj Napoca. 2011;39(1):307-316.

25. Sá FP, Portes DC, Wendling I, Zuffellato-Ribas KC. Miniestaquia de erva-mate em quatro épocas do ano (Minicutting technique of yerba mate in four seasons of the year). Ciência Florestal. 2018 Oct;28(4):1431-1442.

26. Bandurski RS, Cohen JD, Slovin JP, Reinecke DM. Auxin biosynthesis and metabolism. In: Davies PJ, editor. Planthormones. Dordrecht: Kluwer Academic Publishers; 1995. p. 39-65.

27. Lee TT, Starratt AN, Jevnikar JJ. Regulation of enzymic oxidation of indole-3-acetic acid by phenols: structureactivity relationships. Phytochemistry. 1982;21(3):517-523.

28. AsImoshtagui E, Shahsavar AR. Endogenous soluble sugars, starch contents and phenolic compounds in easy and difficult to root Olive cuttings. J Biol Environ Sci. 2010;4(11):83-86.

29. McDowell EM, Trump BF. Histologic fixatives suitable for diagnostic light and electron microscopy. Arch Pathol Lab Med. 1976;100(8):405-414.

30. Gabriel BL. Biological electron microscopy. New York: Van Nostrand Reinhold Company;1982.

31. O'Brien TP, McCully ME. The study of plant structure principles and selected methods. Melbourne: Termarcarphi Pty Ltd.;1981. 357 p.

32. Gerrits PO, Smid L. A new less toxic polymerization system for the embedding of soft tissue in glycol methacrylate and subsequent preparing of serial sections. J Microsc. 1983 Oct;132:81-85.

33. Sidman RL, Mottla PA, Feder N. Improved polyester wax embedding for histology. Stain Technol. 1961;36(5):279284.

34. Roeser KR. Die nadel der schwarzkiefer-massen produckt und kunstwerk der natur. Mikrokosmos. 1972;6(1):3336.

35. Kraus JE, Sousa HC, Rezende MH, Castro NM, Vecchi C, Luque R. Astra Blue and Basic Fuchsin double staining of plant materials. Biotech Histochem. 1998 May;73(5):235-243.

36. Johansen DA. Plant microtechnique. New York: McGraw-Hill Book Company; 1940. 523 p.

37. O'Brien TP, Feder N, McCully ME. Polychromatic staining of plant cell walls by toluidine blue. Protoplasma. 1964;59(2):368-373.

38. Martin FV. Staining and observating pollen tubes in the style by means of fluorescence. Stain Technol. 1959;34:125-128.

39. Kraus JE, Arduin M. Manual básico de métodos em morfologia vegetal. Seropédia: EDUR; 1997. 198 p.

40. Franklin GL. Preparation of thin sections of synthetic resins and wood-resin composites, and a new macerating method for wood. Nature. 1945;155(3924):51.

41. Moreira MF, Appezzato-da-Glória B, Zaidan LB. Anatomical aspects of IBA-treated microcuttings of Gomphrena macrocephala St.-Hil. Braz Arch Biol Technol. 2000 Feb; 43(2):221-227.

42. Ferriani AP, Mayer JLS, Zuffellato-Ribas KC, Bona C, Koehler HC, Deschamps C, et al. Estaquia e anatomia de vassourão-branco (Cutting and anatomy of vassourão-branco). Sci Agrar. 2008;9(2):159-166.

43. Schwarz JL, Glocke PL, Sedgley M. Adventitious root formation in Acacia baileyana F. Muell. J Hortic Sci Biotechnol. 1999 Sep;74(5):561-565.

44. Osterc G, Stampar F. Maturation changes auxin profile during the process of adventitious rooting in Prunus. Eur $\mathrm{J}$ Hortic Sci. 2015 Oct;80(5):225-230.

45. Pimentel N, Lencina KH, Pedroso MF, Somavilla TM, Bisognin DA. Morphophysiological quality of yerba mate plantlets produced by mini-cuttings. Semin Cienc Agrar. 2017 Nov;38(6):3515-3528.

46. Trobec M, Stampar F, Veberic R, Osterc G. Fluctuations of different endogenous phenolic compounds and cinnamic acid in the first days of the rooting process of cherry rootstock 'GiSelA 5'leafy cuttings. J Plant Physiol. 2005 May;162:589-597.

47. De Klerk GJ, Van Der Krieken W, Jong JC. The formation of adventitious roots: new concepts, new possibilities. In Vitro Cell Dev Biol Plant. 1999 May;35(3):189-199.

(C) 2020 by the authors. Submitted for possible open access publication under the terms and conditions of the Creative Commons Attribution (CC BY NC) license (https://creativecommons.org/licenses/by-nc/4.0/). 